1. Half of insured adults with high-deductible health plans experience medical bill or debt problems. Washington, D.C.: The Commonwealth Fund, January 27, 2005. (Accessed April 14, 2005, at http:// www.cmwf.org/newsroom/newsroom_show.htm?doc_id=257751.) 2. Martin JC, Avant RF, Bowman MA, et al. The future of family medicine: a collaborative project of the family medicine community. Ann Fam Med 2004;2:Suppl 1:S3-S32.

3. Levine $S$. District health system faulted. Washington Post. January 29, 2005:B1.

4. Institute of Medicine. Insuring America's health: principles and recommendations. Washington, D.C.: National Academies Press 2004 .

TO THE EDITOR: Rodney Rogers of Woodbury, Tennessee, could have been one of the 323,000 people eliminated from TennCare (the Tennessee Medicaid program) as a cost-saving measure back in 2005 . His myocardial infarction in 2015 might have been prevented if he had had access to care 10 years earlier. Where is the "common-sense efficiency" Dr. Frist details in the current spate of Medicaid reductions?

Rosemary M. Harris, M.D.

Drexel University School of Medicine

Philadelphia, PA 19129

rh39@drexel.edu
TO THE EDITOR: Nothing less than creative, strategic thinking is needed to improve our nation's health care system. Dr. Frist's vision crystallizes many of the forward-thinking ideas currently under discussion by leaders across the health care and political spectrum.

The American Medical Association is deeply concerned that without action our health care system will crumble. Through leadership, education, and advocacy, we are working to expand coverage to the nation's uninsured, reform our broken medicalliability system, ensure fair payments to physicians participating in Medicare and managed-care programs, improve the quality and safety of care for our patients, and improve public health.

\section{John C. Nelson, M.D., M.P.H.}

American Medical Association

Chicago, IL 60610

\title{
Avian Influenza and Pandemics
}

TO THE EDITOR: With an eye to the ominous storm on the horizon that is avian influenza, in his editorial (Jan. 27 issue) ${ }^{1}$ Stöhr proposes a much-needed research agenda - with one major oversight. In addition to clinical and epidemiologic questions, many ethical issues will undoubtedly be raised by an influenza pandemic. The outbreak of the severe acute respiratory syndrome taught us a number of important lessons, but the first was that we were ill prepared to respond. ${ }^{2}$ Among the greatest challenges faced were the duty to provide care in the context of unknown risk, the need to balance individual privacy rights and the public's right to know, the use of quarantine and other restrictive measures, and the need to set priorities and use limited resources appropriately. Other issues were related to information sharing, patents, and research ethics. 3,4

Avian influenza presents a significant, gathering threat. Although it is indeed prudent to pursue a greater understanding of it and to erect safeguards to protect against pandemic spread, it is no less in- cumbent on us to ensure that those safeguards are both reasonable and justifiable.

C. Shawn Tracy, M.Sc.

Sunnybrook and Women's College Health Sciences Centre

Toronto, ON M4N 3M5, Canada

shawn.tracy@sw.ca

Ross E.G. Upshur, M.D.

University of Toronto Joint Centre for Bioethics

Toronto, ON M5G 1L4, Canada

Abdallah S. Daar, D.Phil.

McLaughlin Centre for Molecular Medicine Toronto, ON M5G 2Cl, Canada

1. Stöhr K. Avian influenza and pandemics - research needs and opportunities. N Engl J Med 2005;352:405-7.

2. National Advisory Committee on SARS and Public Health. Learning from SARS: renewal of public health in Canada. Ottawa: Health Canada, October 2003. (Accessed April 14, 2005, at http:// www.hc-sc.gc.ca/english/protection/warnings/sars/learning.html.) 3. Singer PA, Benatar SR, Bernstein M, et al. Ethics and SARS: lessons from Toronto. BMJ 2003;327:1342-4.

4. Bernstein M, Hawryluck L. Challenging beliefs and ethical concepts: the collateral damage of SARS. Crit Care 2003;7:269-71. 